European Journal of Accounting, Auditing and Finance Research

Vol.8, No. 6, pp.46-63, June 2020

Published by ECRTD-UK

Print ISSN: 2053-4086(Print), Online ISSN: 2053-4094(Online)

\title{
CEO CHARACTERISTICS AND DIVIDEND PAYOUT IN SUB-SAHARAN AFRICA
}

\author{
Kumshe, Ahmed Modu ${ }^{1}$ \\ Anaso, Ijeoma Ogochukwu² \\ Gulani, Musa Garba ${ }^{2}$ \\ amkumshe@gmail.com \\ oianaso@yahoo.com \\ musagln1@gmail.com
}

1. Institute of Chartered Accountants of. Nigeria

Plot 16, Idowu. Taylor, Victoria Island, Lagos

2. Department of Accounting

Faculty of Management Sciences, University of Maiduguri

\begin{abstract}
The study examined the effect of CEO characteristics of tenure, nationality, gender and share ownership on the dividend paid by sixty-four companies located in Sub-Saharan Africa. It used data for five years (from 2012 to 2016) and covered three Sub-Saharan African countries. Twenty companies were selected from the sixty-five listed on the Kenyan Stock Exchange; twentythree from the one hundred and seventy-two on the Nigerian Stock Exchange and twenty-one of the three hundred and seventy-six companies listed on Johannesburg Stock Exchange. Kruskal Wallis was applied to test four hypotheses. Two CEO characteristics - nationality and share ownership - were found to have significant relationship to dividend payout in the data available for the study.
\end{abstract}

KEY WORDS: CEO tenure, CEO nationality, CEO gender, CEO share ownership, dividend payout, Sub-Saharan Africa

\section{INTRODUCTION}

The Sub-Saharan Africa has been an area of research interest but very little research results have been published in that area. This paradox persisted due to the lack of credible data sources in the sub-region. This situation is however changing, bringing about enough opportunities to explore research agendas that have been studied sufficiently in the West. Dividend policy of companies is a mature area of research, especially in developed economies. Individual studies have been carried out within sub-Saharan Africa, but few studies, if any, have explored the dividend policy in the Sub-Saharan Africa context. This study starts with a review of the determinants of dividend policy, explores the role of Chief Executive Officer (CEO) characteristics in the determination of dividend before proposing four hypotheses for analysis. Obviously, the region still has severe data limitation, however, this study is an attempt to bridge the gap between studies that have previously been carried out using available data sources.

\section{Determinants of Dividend Policy}

Onali, Galiakhmetova, Molyneux, and Torluccio (2016) assert that dividend policy is one of the cornerstones of financial economics and extensive literature has evolved since Miller and Modigliani's (1961) seminal work on the irrelevance of dividend policy. In the presence of taxes, 
European Journal of Accounting, Auditing and Finance Research

Vol.8, No. 6, pp.46-63, June 2020

Published by ECRTD-UK

Print ISSN: 2053-4086(Print), Online ISSN: 2053-4094(Online)

a zero-dividend policy would be optimal (Farrar, Farrar \& Selwyn 1967). Yet, firms do pay dividends. Subsequent studies have sought to test Miller and Modigliani's proposition to see if the results derived from theory hold in real financial markets - where the assumptions of perfect information, no tax and agency costs, typically do not hold (Lease, John, Kalay, Loewensten \& Sarig 2000).

Empirical literature spans an array of areas covering dividend policy and how it relates to tax clienteles (Elton \& Gruber, 1970), agency costs (Easterbrook, 1984), signaling effects (Aharony \& Swary, 1980), life-cycle factors (DeAngelo, DeAngelo, \& Stulz, 2006), catering incentives (Baker \& Wurgler, 2004), and behavioral factors (Turner, Ye, \& Zhan, 2013). One branch of the literature focuses on the relation between managerial entrenchment and dividend policy. The entrenchment hypothesis argues that managers who fear disciplinary actions tend to pay higher dividends as a protection against such actions (Zwiebel, 1996; Fluck, 1999; Allen, Bernardo \& Welch, 2000). This hypothesis is grounded in the principle that dividends are paid to decrease agency costs between managers and shareholders (Easterbrook, 1984; Jensen, 1986). By paying dividends, managers increase the utility of outside shareholders and decrease monitoring incentives. Literature on non-financial firms typically support the entrenchment hypothesis (Hu \& Kumar, 2004; Elyasiani \& Zhang, 2015). However, the incentive to pay dividends as a monitoring device is negligible for CEOs that can fend off take-over threats (Stulz, 1988). In general, entrenched CEOs are less incentivized to pay large amounts of dividends in the absence of monitoring from minority shareholders (Hu \& Kumar, 2004; Elyasiani \& Zhang, 2015), and when shareholder rights are weak (La Porta, Lopez-de-Silanes, Shleifer \& Vishny, 2000; Alzahrani \& Lasfer, 2012). In the same vein, in the presence of laws that insulate managers from takeovers, dividend payout ratios fall (Francis, Hasan, John \& Song 2011). Bacon and Kania (2005) suggest that dividends serve as an indicator of a company's present and future performance, even of its potential susceptibility to risk. They also found significant positive associations between payout and profit growth and debt. By contrast, Bacon and Kania (2005) found significant negative relationships between payout, risk, capital expenses, insider ownership and liquidity. The existence of insider ownership and the number of common shareholders in dividends models spurred research on the relationship between dividend policies and mechanisms of corporate governance.

Using available financial data of listed firms in the 29 stock exchanges in Africa, Nnadi, Wogboroma, and Kabel (2013) found similarities in the determinants of dividend policy in African firms with those in most developed economies. Agency costs were found to be the most dominant determinant of dividend policy among African firms. Other factors such as level of market capitalization, age and growth of firms, as well as profitability also played key roles in the dividend policy of listed African firms. Patra, Poshakwale and Ow-Yong (2012) assessed the determinants of corporate dividend policy of listed firms in Greece, an emerging market. The study used the Generalized Linear Model (GMM) to estimate the firm level factors that may determine why firms distribute dividends. The study found that size, profitability and liquidity factors increased the probability to pay dividends. Forti, Peixoto and Alves (2015) assessed the determinant factors of dividend payments in Brazil using companies listed on the Brazilian Securities, Commodities and Future Exchange (BM\&F BOVESPA) between 1995 and 2011. Significant positive variable found are firm size, return on assets, market to book, liquidity and profit growth. Similarly, Dalmácio 
European Journal of Accounting, Auditing and Finance Research

Vol.8, No. 6, pp.46-63, June 2020

Published by ECRTD-UK

Print ISSN: 2053-4086(Print), Online ISSN: 2053-4094(Online)

and Corrar (2007) studied the relationship between shareholder control concentrations and the dividend policies of 438 Brazilian companies listed on the São Paulo Stock Exchange (Bolsa de Valores de São Paulo- xBOVESPA) from 1998 to 2005. The authors found that an increase in shareholder concentration raises the value of dividends paid per share.

Feng, Ghosh, He and Sirmans (2010) examines the relationship between CEO entrenchment and dividend policy of Real Estate Investment Trusts (REITs). The results show a strong relationship between CEO entrenchment and dividend policy for REITs without a nomination committee. In the sub-group with nomination committees, CEO entrenchment has less influence on dividend policy. As a significant determinant of CEO entrenchment, CEO involvement in director selection is detrimental to shareholder interest.

Deshmukh, Geol and Howe (2013) developed a model of the effect of CEO overconfidence on dividend policy and empirically examined many of its predictions. It was found that the level of dividend payout is lower in firms managed by overconfident CEOs. It was documented that this reduction in dividends associated with $\mathrm{CEO}$ overconfidence is greater in firms with lower growth opportunities, lower cash flow, and greater information asymmetry. It also showed that the magnitude of the positive market reaction to a dividend-increase announcement is lower for firms managed by overconfident CEOs. Overall results are consistent with the predictions of the model.

Khan (2006) investigated the relationship between dividends and ownership structure for a panel of 330 large quoted UK firms. Controlling for unobserved firm-specific effects, results indicate a negative relationship between dividends and ownership concentration. Ownership composition also matters, with a positive relationship observed for shareholding by insurance companies, and a negative one for individuals. These results are consistent with agency models in which dividends substitute for poor monitoring by a firm's shareholders but can also be explained by the presence of powerful principals who are able to impose their preferred payout policy upon firms.

From the above review, some CEO characteristics (tenure and share ownership) have been shown to relate with the dividend payout of some firms. These previous studies were conducted considering each characteristic alongside some different set of proxies and in different environments. This study aims to assess the relationship between CEO characteristics (tenure, gender, share ownership and nationality) and dividend payout in Sub-Sahara Africa.

\section{CEO Characteristics}

\section{CEO Tenure}

Caliskan and Doukas (2015) assert that, CEO tenure is generally used as a proxy for managerial entrenchment. This entrenchment can be defined as the likelihood of a manager to opt for concentrated power (Berger, Ofek, \& Yermack, 1997; Hu \& Kumar, 2004) or risk aversion (Coles, Daniel \& Naveen, 2006), both of which indicate that CEOs with longer tenure are less likely to increase firm value and as such they pay more dividends as opposed to investing in valueincreasing projects (Caliskan \& Doukas 2015).

Jo and Pan (2009) examined the relationship between managerial entrenchment and dividend policies for United States industrial firms from 1990 to 2003. The authors adopted logit and tobit 
European Journal of Accounting, Auditing and Finance Research

Vol.8, No. 6, pp.46-63, June 2020

Published by ECRTD-UK

Print ISSN: 2053-4086(Print), Online ISSN: 2053-4094(Online)

estimators to measure managerial entrenchment via the Gompers, Ishii and Metrick GIM's GIndex (Gompers, Ishii \& Metrick, 2003). They found that firms with entrenched managers are more likely to pay dividends and that doing so lowers cash holdings, thus rendering firms more vulnerable to hostile takeovers. Al Ghazali (2014) however, opined that increased CEO tenure increases his power over the board, and hence he forces a reduction in dividends to find new projects internally. Likitratcharoen, Jiraporn and Kanitpong (2012) found out that CEO tenure showed a significant negative association with the propensity to pay dividends. The authors asserted in their study that over the past decades, there have been numerous discussions about the influence of dividends and firm's value. If dividends have an influence on the firm's value, then it is worth exploring the factors that have an influence on dividends. The study tested the association between firm's propensity to pay dividends and firm's CEO reputation while controlling for firm size, market-to-book ratio, leverage, R\&D spending, capital expenditures, CEO tenure, year dummies, and industry dummies. Press coverage (media counts) are used to proxy for CEO reputation. The results from logistic regression show that firms with higher reputable CEOs have lower propensity to pay dividends. These results support the investment hypothesis that CEOs with higher reputation tend to be more aggressive and use the funds to make more investment rather than paying out dividends.

Onali, Galiakhmetova, Molyneux and Torluccio (2015) employed three main proxies for CEO power: CEO ownership, CEO tenure, and unforced CEO turnover to investigate the role of CEO power and government monitoring on bank dividend policy for a sample of 109 European listed banks for the period 2005-2013. The study showed that CEO power has a negative impact on dividend payout ratios and on performance, suggesting that entrenched CEOs do not have the incentive to increase payout ratios to discourage monitoring from minority shareholders. Likitratcharoen (2011) investigates the relationship between CEO reputation (of which CEO tenure was among the proxies used) and firm's dividend payouts. The results show that reputable CEOs tend to make more investment and pay lower dividends. On the basis of the above, the first hypothesis is proposed:

$\mathrm{H}_{1}$ : CEO Tenure has no significant effect on dividend payout among listed companies in SubSaharan Africa.

\section{CEO Nationality}

CEO nationality has been used as a proxy for CEO's international experience or managerial style (Sebbas, 2017). Jalbert, Terrance, Chan, Jalbert and Landry (2007) examined the backgrounds of the highest paid Chief Executive Officers (CEOs) in the United States. Specifically, they investigated the extent to which national origin, affected salaries received, the way firms were managed and how firms performed. The study relied on the Forbes 800 CEO compensation data. The data (from 1991-1997) and included 4,834 observations. Regressions determined the extent to which the birthplace of the CEO affected the salary that the CEO received, along with the capital structure, dividend policy and return on assets of the firm. The results indicated that CEOs with differing nationalities were compensated differently and operated their firms differently than US born CEOs. The compensation of the CEOs was found to be higher for some groups of foreign 
European Journal of Accounting, Auditing and Finance Research

Vol.8, No. 6, pp.46-63, June 2020

Published by ECRTD-UK

Print ISSN: 2053-4086(Print), Online ISSN: 2053-4094(Online)

born CEOs. Some evidence of differing capital structures was found. However, the results were not significant after incorporating the full set of control variables into the regressions. CEOs from Central and South America paid out larger percentages of firm earnings to owners in the form of dividends than other CEOs. Finally, the study found some evidence to suggest that Central and South America born CEOs, and Australian and New Zealand born CEOs earned a higher return on assets than other CEOs.

Sabbes (2017) inferred that the nationality of CEOs and its implication are different in European setting than in an American one due to the broader cultural diversity at play in Europe. It can also be inferred that since the cultural context in Africa is different from both the American and European setting, a study in the current setting is necessary to confirm the generalizability of the findings of previous studies.

Studies on CEO nationality have adopted the upper-echelons theory. The theory has two interconnected parts - (1) executives act on the basis of their personalized interpretations of the strategic situations they face, and (2) these personalized construals are a function of the executives' experiences, values, and personalities. The theory is built on the premise of bounded rationality. Interest in executive effects in different national systems and research is encouraged in advancing understanding of how upper echelon theory might take on very different complexions, depending on the macrosocial context (Hambrick, 2007). CEO with foreign origin are proposed to have international experience and it is further proposed that foreign CEOs will pay larger dividends than indigenous CEOs.

$\mathrm{H}_{2}$ : CEO nationality has no significant effect on dividend payout in listed companies in subSaharan Africa.

\section{CEO Gender}

Chen, Leung, and Goergen (2017) sought to discover if female independent directors were more likely to pay high dividend payouts. It was discovered that firms with a larger fraction of female directors on their board had greater dividend payouts. Result of different research were mixed: negative relation (Schrader, Blackburn \& Iles, 1997), while others found no significant relation (Zahra \& Stanton, 1998), or a positive relation (Carter, Simkins \& Simpson, 2003; Francoeur, Labelle \& Sinclair- Desgagné, 2008). The differences found between male and female was in their appetite for risk. Female executives were found to be more risk averse than their male counterparts (Croson \& Gneezy, 2009). Female executives were also found to be less aggressive in strategy choices and invested in more sustainable projects (Apesteguia, Azmat, \& Iriberri, 2012).

Martin, Nishikawa and William (2009) used a sample of 70 female and male CEO appointments over 1992-2007 to study effects of gender on valuation and risk. The result of the study found female CEOs were relatively more risk averse than their male counterpart. Similarly, Davis, Babakus, Englis and Pett (2010) examines the effects of CEO gender on market orientation and performance (growth and profitability) among a sample of small and medium-sized service businesses. Gender was found to have significant indirect effects (via market orientation) on both 
European Journal of Accounting, Auditing and Finance Research

Vol.8, No. 6, pp.46-63, June 2020

Published by ECRTD-UK

Print ISSN: 2053-4086(Print), Online ISSN: 2053-4094(Online)

market performance (growth) and financial performance (profitability). That is, female-led service SMEs perform significantly better due to their stronger market orientation relative those led by males. The findings further suggest that female-led firms were slightly better than their male-led counterparts in transmitting market performance into financial performance, although the differences were not statistically significant. Joecks, Pull and Vetter (2012), found a U-shaped relationship between women and performance. The reason for this relation lies in group theories which is stated by Kanter (1977). When percentage of women on the board was small, there was a negative effect on firm performance. Rozeff's (1982) tradeoff theory suggests that when the board is performing poorly, more dividend needs to be paid.

$\mathrm{H}_{3}$ : CEO Gender has no significant effect on dividend payout among listed companies in subSaharan Africa.

\section{CEO Share ownership}

When Directors have shares and options of a company, it has an impact on their performance. By owning a part of the company, the interests of Directors are aligned with shareholders and agency costs decreases (Ghosh \& Sirmans, 2006). However, when the Directors have a large part of the shares, takeover threat reduces, and the Directors are entrenched (Morck et al., 1988). Extensive research has been done on the consequences of entrenchment on agency costs. First, leverage will be lower than optimal (Brounen,de Jong \& Koedijk, 2006), debt will have longer maturity (Guney \& Ozkan, 2005), larger amounts of cash will be held (Ozkan \& Ozkan, 2004) and there will be overinvestment (Pawlina \& Renneboog,2005). The evidence given above indicates that the agency cost will decrease when the percentage of shares held by the executive increases. When managers get entrenched, agency cost will start to increase again. Dividend payment is expected to follow the same pattern. Al-Ghazali (2014) find that CEOs stock ownership and option holding are insignificantly correlated with the amount of, and the propensity to pay dividends which is inconsistent with the empirical findings of Deshmukh et al., (2013) who develop a model which shows that, because overconfident CEOs overestimate the value of future projects and view external finance as costly, they are more likely to pay less dividends. However, none of these studies have theoretically considered the influence of agency problems on this relationship.

$\mathrm{H}_{4}$ : CEO share ownership has no significant effect on dividend payout among listed companies in sub-Saharan Africa.

It can be seen from the above literature that CEO characteristics: tenure, nationality, gender and share ownership affect dividend payout of a firm. Previous research conducted focused on each characteristic, alongside some different set of proxies and in different geographical environments. Considering the use of unique set of CEO characteristics in this study and in African environment will be an addition to the existing literature.

\section{Study Rationale}

The purpose of the study is to ascertain the effect of CEO characteristics reviewed above on the dividend payout in companies in Sub-Saharan. Africa. Many of the previous studies were carried 
European Journal of Accounting, Auditing and Finance Research

Vol.8, No. 6, pp.46-63, June 2020

Published by ECRTD-UK

Print ISSN: 2053-4086(Print), Online ISSN: 2053-4094(Online)

out in America (Jalbert, Terrance, Chan, Jalbert \& Landry, 2007), Europe (Onali, Galiakhmetova, Molyneux \& Torluccio, 2015), Greece, among others. Given that Sub-Saharan Africa has a different level of economic development, it would add to existing literature to examine the relationship between CEO characteristics and dividend payout in that context. The study will provide a unique understanding of how different CEO characteristics affect the dividend payout of companies located in Sub-Saharan Africa. It is believed that a sub-region study may bring perspectives that may not be perceived from single country studies.

\section{METHODOLOGY}

Data used for this study was made available through MacameRatios@ database. The data comprised of the following: CEO tenure was derived as " 1 " for companies whose CEOs have stayed for three years and " 0 " otherwise (that is less than three years); CEO Nationality was also determined dichotomously using " 1 " for companies with foreign CEOs and " 0 " otherwise; CEO gender was a computed as " 1 " for companies with female CEOs and " 0 " for companies with male CEOs; and CEO share ownership was derived as the percentage of CEO shares to total shares held by others. The study used data for five years (from 2012 to 2016) and covered three sub-Saharan African countries: Kenya, Nigeria and South Africa. The year 2012 - 2016 were assigned "1" to "5" consecutively; Kenya was assigned "1", Nigeria "2" and South Africa "3" for analyses purposes. Twenty companies were selected from the sixty-five listed on the Kenyan stock exchange; twenty-three from the one hundred and seventy-two on the Nigerian stock exchange and twenty-one of the three hundred and seventy-six companies listed on Johannesburg stock exchange. The choices were purely based on availability and convenience. STATA 13 was used for both descriptive and inferential analysis.

Cash Dividend to Asset Ratio; Return on Assets and Tobin's Q for the listed companies in the three countries are used in the analyses. Cash dividend to asset ratio was used as a proxy for dividend payout, as using the absolute dividend figure would not have appropriately represented dividend payout. Return on Asset (ROA) is a financial indicator of how profitable a company is relative to its total assets. It gives an idea as to how efficient management is at using its assets to generate earnings. Tobin's Q, a ratio, is a measure of firm assets in relation to a firm's market value, that is total market value of the firm divided by total asset value of the firm.

\section{DISCUSSION}

Data collected had the characteristics shown in Table 1:

Table 1: General Descriptive Statistics

\begin{tabular}{|l|r|r|r|}
\hline Statistics & \multicolumn{1}{|c|}{$\begin{array}{c}\text { Cash Dividend to } \\
\text { Assets }\end{array}$} & $\begin{array}{c}\text { Return on Assets } \\
\text { (ROA) }\end{array}$ & \multicolumn{1}{|c|}{ TobinQ } \\
\hline Count & 320 & 320 & 320 \\
\hline Mean & 4.577875 & 7.588156 & 1.445 \\
\hline Median; $\mathrm{p} 50$ & 2.175 & 4.665 & 66.61 \\
\hline Maximum & 60.85 & 103.16 & .4 \\
\hline Minimum & 0 & -20.16 & 6.367021 \\
\hline Standard Deviation & 7.430277 & 11.16183 & \\
\hline
\end{tabular}

Source: STATA 13 output 
European Journal of Accounting, Auditing and Finance Research

Vol.8, No. 6, pp.46-63, June 2020

Published by ECRTD-UK

Print ISSN: 2053-4086(Print), Online ISSN: 2053-4094(Online)

From Table 1, cash dividend to asset ratio ranged from a maximum of 60.85 to a minimum of 0 ; the mean of cash dividend to asset ratio was 4.6 and standard deviation bout 7.43. The data signified a wide range among the variable. The maximum Return on Assets was 103.16 and the lowest was a negative; mean was 7.59 and standard deviation 11.16, also signifying wide variance in the figures. Highest value for TobinQ was 66.61, and lowest was 0.4, mean was 3.18 and standard deviation 6.37, also signifying wide variances in the variable. To be able to scrutinize the information better, the descriptive statistics was analyzed by country, as found in Table 2:

Table 2: Descriptive by Country

\begin{tabular}{|c|c|c|c|c|}
\hline Country & Statistics & $\begin{array}{l}\text { Cash Dividend to } \\
\text { Assets }\end{array}$ & ROA & TobinQ \\
\hline \multirow[t]{6}{*}{ Kenya } & Count & 100 & 100 & 100 \\
\hline & Mean & 4.4051 & 6.9211 & 1.7865 \\
\hline & Median; p50 & 1.555 & 4.165 & 1.21 \\
\hline & Maximum & 40.73 & 41.19 & 9.12 \\
\hline & Minimum & 0 & -19.23 & .4 \\
\hline & Standard Deviation & 7.223628 & 9.180023 & 1.591078 \\
\hline \multirow[t]{6}{*}{ Nigeria } & Count & 115 & 115 & 115 \\
\hline & Mean & 5.342 & 7.830783 & 2.297478 \\
\hline & Median; p50 & 2.09 & 4.66 & 1.34 \\
\hline & Maximum & 60.85 & 53.96 & 11.78 \\
\hline & Minimum & 0 & -20.16 & .68 \\
\hline & Standard Deviation & 9.729487 & 10.2321 & 2.106854 \\
\hline \multirow{6}{*}{$\begin{array}{l}\text { Republic } \\
\text { of South } \\
\text { Africa }\end{array}$} & Count & 105 & 105 & 105 \\
\hline & Mean & 3.905524 & 7.830783 & 5.480381 \\
\hline & Median; p50 & 3.12 & 5.88 & 1.99 \\
\hline & Maximum & 18.7 & 103.16 & 66.61 \\
\hline & Minimum & 0 & -5.22 & .42 \\
\hline & Standard Deviation & 3.843832 & 13.65761 & 10.44026 \\
\hline \multirow[t]{6}{*}{ Total } & Count & 320 & 320 & 320 \\
\hline & Mean & 4.577875 & 7.588156 & 3.182188 \\
\hline & Median; p50 & 2.175 & 4.665 & 1.445 \\
\hline & Maximum & 60.85 & 103.16 & 66.61 \\
\hline & Minimum & 0 & -20.16 & .4 \\
\hline & Standard Deviation & 7.430277 & 11.16183 & 6.367021 \\
\hline
\end{tabular}

Source: STATA 13 Output

From Table 2, it can be observed that even though Nigeria had the highest cash dividend to asset figure, the Republic of South Africa had the highest Return on assets and Tobin Q. Further analysis is seen in Tables 3, 4, 5 and 6. In Table 3, the data was analyzed based on CEO tenure and it became obvious that companies with CEOs that have had 3 years tenure have higher cash dividend to assets and return on assets than companies whose CEO have been in leadership for less than three years. However, companies whose CEOs have not been in leadership for up to three years have higher Tobin Q measures. 
European Journal of Accounting, Auditing and Finance Research

Vol.8, No. 6, pp.46-63, June 2020

Published by ECRTD-UK

Print ISSN: 2053-4086(Print), Online ISSN: 2053-4094(Online)

Table 3: Descriptive by CEO Tenure

\begin{tabular}{|c|c|c|c|c|}
\hline Country & Statistics & $\begin{array}{l}\text { Cash Dividend to } \\
\text { Assets }\end{array}$ & ROA & TobinQ \\
\hline \multirow{6}{*}{$\begin{array}{lr}\text { CEO has } \\
\text { been in } \\
\text { position less } \\
\text { than three } \\
\text { years }\end{array}$} & Count & 68 & 68 & 68 \\
\hline & Mean & 4.762647 & 5.991471 & 4.814853 \\
\hline & Median; p50 & 2.815 & 4.475 & 1.46 \\
\hline & Maximum & 35.18 & 41.19 & 66.61 \\
\hline & Minimum & 0 & -20.16 & .4 \\
\hline & Standard Deviation & 5.806082 & 8.114266 & 10.87999 \\
\hline \multirow{6}{*}{$\begin{array}{l}\text { CEO has } \\
\text { been in } \\
\text { position } \\
\text { three years } \\
\text { or more }\end{array}$} & Count & 252 & 252 & 252 \\
\hline & Mean & 4.528016 & 8.019008 & 2.741627 \\
\hline & Median; p50 & 2.115 & 4.665 & 1.14 \\
\hline & Maximum & 60.85 & 103.16 & 50.65 \\
\hline & Minimum & 0 & -19.23 & .4 \\
\hline & Standard Deviation & 7.82022 & 11.82738 & 4.359671 \\
\hline \multirow[t]{6}{*}{ Total } & Count & 320 & 320 & 320 \\
\hline & Mean & 4.577875 & 7.588156 & 3.182188 \\
\hline & Median; p50 & 2.175 & 4.665 & 1.445 \\
\hline & Maximum & 60.85 & 103.16 & 66.61 \\
\hline & Minimum & 0 & -20.16 & .4 \\
\hline & Standard Deviation & 7.430277 & 11.16183 & 6.367021 \\
\hline
\end{tabular}

Source: STATA 13 output

In Table 4, the data was grouped based on CEO nationality and it was found that companies with indigenous CEOs had higher cash dividend to assets than those with foreign CEOs; companies with foreign CEOs however had higher return on assets and Tobin Q than those with indigenous CEOs.

Table 4: Descriptive by CEO Nationality

\begin{tabular}{|c|c|c|c|c|}
\hline CEO Nat & Statistics & $\begin{array}{l}\text { Cash Dividend to } \\
\text { Assets }\end{array}$ & ROA & TobinQ \\
\hline \multirow{6}{*}{$\begin{array}{l}\text { Indigenous } \\
\text { CEO }\end{array}$} & Count & 153 & 153 & 153 \\
\hline & Mean & 3.36085 & 5.67366 & 1.50902 \\
\hline & Median; p50 & 1.29 & 3.6 & 1.09 \\
\hline & Maximum & 60.85 & 53.96 & 11.78 \\
\hline & Minimum & 0 & -20.16 & .4 \\
\hline & Standard Deviation & 8.275281 & 9.454448 & 1.471052 \\
\hline \multirow{6}{*}{$\begin{array}{l}\text { Foreign } \\
\text { CEO }\end{array}$} & Count & 167 & 167 & 167 \\
\hline & Mean & 5.692874 & 9.342156 & 4.71509 \\
\hline & Median; p50 & 3.38 & 7.16 & 2.16 \\
\hline & Maximum & 40.73 & 103.16 & 66.61 \\
\hline & Minimum & 0 & -19.23 & .42 \\
\hline & Standard Deviation & 6.385431 & 12.29207 & 8.424814 \\
\hline \multirow[t]{6}{*}{ Total } & Count & 320 & 320 & 320 \\
\hline & Mean & 4.577875 & 7.588156 & 3.182188 \\
\hline & Median; p50 & 2.175 & 4.665 & 1.445 \\
\hline & Maximum & 60.85 & 103.16 & 66.61 \\
\hline & Minimum & 0 & -20.16 & $\begin{array}{llll}.4 & & & \\
\end{array}$ \\
\hline & Standard Deviation & 7.430277 & 11.16183 & 6.367021 \\
\hline
\end{tabular}

Source: STATA 13 Output 
European Journal of Accounting, Auditing and Finance Research

Vol.8, No. 6, pp.46-63, June 2020

Published by ECRTD-UK

Print ISSN: 2053-4086(Print), Online ISSN: 2053-4094(Online)

Table 5 displays the data by CEO gender, and it was discovered that a company managed by female CEOs had the highest mean for cash dividend to asset, return on assets and Tobin Q. The highest value for cash dividend to asset was found in a company managed by a female CEO, while companies managed by male CEOs showed the highest for return on assets and Tobin Q numbers.

Table 5: Descriptive by Gender

\begin{tabular}{|c|c|c|c|c|}
\hline CEO Nat & Statistics & $\begin{array}{l}\text { Cash Dividend to } \\
\text { Assets }\end{array}$ & ROA & TobinQ \\
\hline \multirow[t]{6}{*}{ Male CEO } & Count & 305 & 305 & 305 \\
\hline & Mean & 4.003443 & 7.077738 & 3.170393 \\
\hline & Median; p50 & 2.16 & 4.59 & 1.46 \\
\hline & Maximum & 40.73 & 103.16 & 66.61 \\
\hline & Minimum & 0 & -20.16 & .4 \\
\hline & Standard Deviation & 5.337364 & 10.30587 & 6.47386 \\
\hline \multirow[t]{6}{*}{ Female CEO } & Count & 15 & 15 & 15 \\
\hline & Mean & 16.258 & 17.96667 & 3.422 \\
\hline & Median; p50 & 4.37 & 7.7 & 1.14 \\
\hline & Maximum & 60.85 & 53.96 & 11.78 \\
\hline & Minimum & 0 & 1.2 & .96 \\
\hline & Standard Deviation & 22.04616 & 20.28332 & 3.685094 \\
\hline \multirow[t]{6}{*}{ Total } & Count & 320 & 320 & 320 \\
\hline & Mean & 4.577875 & 7.588156 & 3.182188 \\
\hline & Median; p50 & 2.175 & 4.665 & 1.445 \\
\hline & Maximum & 60.85 & 103.16 & 66.61 \\
\hline & Minimum & 0 & -20.16 & .4 \\
\hline & Standard Deviation & 7.430277 & 11.16183 & 6.367021 \\
\hline
\end{tabular}

Source: STATA 13 output

The data was then tested for normality using Skewness/Kurtosis test for normality. This is displayed in Table 5. The test for normality revealed that the data on return on asset, Tobin Q, cash dividend to assets, CEO tenure, nationality, gender and share ownership. Normality is a necessary assumption in determining what further statistical tests can be carried out on the data. Normality is found when Prob>chi2 is more than 0.10. The data was not normally distributed. The significance of the this is that parametric statistical tool may not be applied in the test of hypotheses. However, non-parametric test can be carried out, and the study used the Kruskal-Wallis H test. 
European Journal of Accounting, Auditing and Finance Research

Vol.8, No. 6, pp.46-63, June 2020

Published by ECRTD-UK

Print ISSN: 2053-4086(Print), Online ISSN: 2053-4094(Online)

Table 6: Result from Normality Test

\begin{tabular}{|l|l|r|r|r|r|}
\hline Variable & Observations & Pr(Skewness) & Pr(Kurtosis) & \multicolumn{2}{|c|}{ Joint } \\
& & & & adj chi2(2) & Prob>chi2 \\
\hline ROA & 320 & 0.0000 & 0.0000 & - & 0.0000 \\
\hline Tobin Q & 320 & 0.0000 & 0.0000 & - & 0.0000 \\
\hline CaDiv to Ass & 320 & 0.0000 & 0.0000 & - & 0.0000 \\
\hline CEO Tenure & 320 & 0.0000 & 0.9183 & 50.28 & 0.0000 \\
\hline CEO Nat & 320 & 0.5140 & & - & - \\
\hline CEO Gender & 320 & 0.0000 & 0.0000 & - & 0.0000 \\
\hline CEO shareO & 320 & 0.0000 & 0.0000 & - & 0.0000 \\
\hline
\end{tabular}

Source: STATA 13 output

\section{Test of Hypotheses}

Before the Kruskal-Wallis $\mathrm{H}$ Test can be carried out, it is necessary to ensure all its assumptions are met:

i. The two variables should be measured in an ordinal scale or a continuous scale (that is, interval or ratio scale;

ii. The independent variable should consist of two or more categorical, independent (unrelated) groups;

iii. There must be independence of observations, that is, no relationship between the observations in each group or between the groups themselves; and

iv. All groups must have the same shape of distribution.

These assumptions were met by the data and the Kruskal-Wallis $\mathrm{H}$ Test was conducted. The first hypothesis sought to test the significant effect of CEO tenure on dividend payout in subSaharan Africa. The STATA 13 output revealed that there was no significant relationship between CEO tenure and dividend payout for the data analyzed. This is because the $p$ value is 21.33 percent (greater than 5 percent). Thus, there is insufficient evidence to reject the null hypothesis that the groups (that is, CEO with tenure less than three years and otherwise) that the group medians are equal. The result is displayed in Table 7.

Table 7: Kruskal-Wallis Result for CEO Tenure and Dividend payout.

\begin{tabular}{|l|l|l|}
\hline CEO Tenure & Observations & Rank Sum \\
\hline CEO stay less than 3 years & 68 & 11756.50 \\
\hline CEO stay, 3 years or more & 252 & 39603.50 \\
\hline
\end{tabular}

Source: STATA 13 output

Chi-square $=1.548$ with 1 degree of freedom

probability $=\mathbf{0 . 2 1 3 4}$

Chi-square with ties $=1.549$ with 1 degree of freedom

probability $=\mathbf{0 . 2 1 3 3}$ 
European Journal of Accounting, Auditing and Finance Research

Vol.8, No. 6, pp.46-63, June 2020

Published by ECRTD-UK

Print ISSN: 2053-4086(Print), Online ISSN: 2053-4094(Online)

Hypothesis two, which tests the relationship between CEO nationality and dividend payout was also tested. STATA 13 revealed a significant relationship between CEO nationality and the dividend payout for the data analyzed. This is revealed by the $p$ value of the Kruskal-Wallis equality-of-populations rank test was 0.0001 (less than 5 percent). The study therefore rejects the null hypothesis which stated that CEO nationality has no significant effect on dividend payout in companies in sub-Saharan Africa. This is in line with previous findings (Jalbert, et al., 2007) which found differences in CEO propensity to pay out higher dividend based on nationality/birth place. The result is displayed in Table 8 .

Table 8: Kruskal-Wallis Result for CEO Nationality and Dividend payout

\begin{tabular}{|l|l|l|}
\hline CEO Nationality & Observations & Rank Sum \\
\hline CEO is indigenous & 153 & 19025.00 \\
\hline CEO is a foreigner & 167 & 32335.00 \\
\hline
\end{tabular}

Source: STATA 13 output

Chi-square $=44.767$ with 1 degree of freedom

Probability $=\mathbf{0 . 0 0 0 1}$

Chi-square with ties $=44.772$ with 1 degree of freedom

Probability $=\mathbf{0 . 0 0 0 1}$

Hypothesis three was designed to test the relationship between CEO gender and dividend payout. Using Kruskal-Wallis equality-of-populations rank test conducted on STATA 13 gave a $p$-value of 0.0920 which is higher than the accepted 5\%. Consequently, there is insufficient evidence to reject the null hypothesis that the group medians are equal (that is the companies managed by female CEOs and companies managed by male CEOs). This is shown in Table 9 below:

Table 9: Kruskal-Wallis Result for CEO Gender and Dividend payout

\begin{tabular}{|l|l|l|}
\hline CEO Gender & Observations & Rank Sum \\
\hline Company has a Male CEO & 305 & 48363.00 \\
\hline Company has a Female CEO & 15 & 2997.00 \\
\hline
\end{tabular}

Source: STATA 13 output

Chi-square $=2.840$ with 1 degree of freedom

Probability $=\mathbf{0 . 0 9 2 0}$

Chi-square $=2.840$ with 1 degree of freedom

Probability $=\mathbf{0 . 0 9 2 0}$

Hypothesis four tested the relationship CEO share ownership and dividend payout. Using the same non-parametric test, CEO share ownership was found to have a significant relationship with the dividend payout of the companies under consideration ( $p$-value 0.0044 , which is less 
European Journal of Accounting, Auditing and Finance Research

Vol.8, No. 6, pp.46-63, June 2020

Published by ECRTD-UK

Print ISSN: 2053-4086(Print), Online ISSN: 2053-4094(Online)

than 5\% level of significance. Consequently, the study rejects the null hypothesis which states that CEO share ownership has no significant effect on dividend payout in companies located in sub-Saharan Africa. This is in line with the result obtained by Deshmukh, et al., (2013) but not in line with Al Ghazali's (2014) study. Please see Table 10 in Appendix I.

Control Variables:

a. Country: The data was also not significant in the relationship between the country (companies are located) and the dividends. So, there were no significant differences among the three countries. See Table 10 below.

Table 11: Kruskal-Wallis test for equality of population -Country

\begin{tabular}{|l|r|r|}
\hline Country & Observations & Rank Sum \\
\hline Kenya & 100 & 14705.00 \\
\hline Nigeria & 115 & 18866.00 \\
\hline South Africa & 105 & 17789.00 \\
\hline
\end{tabular}

Chi-squared $=3.259$ with 2 degrees of freedom

Probability $=0.1961$

Chi-squared with ties $=3.259$ with 2 degrees of freedom

Probability $=0.1960$

b. Company Size - return on assets: there was also no significant differences between the size of the company and its dividends. (Table 12 in appendix I)

Chi-squared $=3.259$ with 2 degrees of freedom

Probability $=0.1961$

Chi-squared with ties $=3.259$ with 2 degrees of freedom

Probability $=0.1960$

c. Ratio of Market value of Company's assets by the replacement value of company's assets

- Tobin Q: There was a significant difference in the dividends paid based on the companies Tobin Q. (Table 13 in appendix II)

Chi-squared $=3.259$ with 2 degrees of freedom

Probability $=0.1961$

Chi-squared with ties $=3.259$ with 2 degrees of freedom

Probability $=0.1960$ 
European Journal of Accounting, Auditing and Finance Research

Vol.8, No. 6, pp.46-63, June 2020

Published by ECRTD-UK

Print ISSN: 2053-4086(Print), Online ISSN: 2053-4094(Online)

\section{CONCLUSION}

The study examined the effect of CEO characteristics of tenure, nationality, gender and share ownership on the dividend payout by sixty-four companies located in sub-Saharan Africa (Kenya - 20 companies; Nigeria - 23 companies; and south Africa - 21 companies). The information on the first three CEO characteristics were captured in the form of dummy variables while the CEO share ownership was not. When the data did not pass normality test, the Kruskal Wallis was applied to test the hypotheses. Two CEO characteristics - nationality and share ownership - were found to have significant relationship to dividend payout in the data available for the study. This study has the implications for shareholders. Shareholders may be able to predict the dividend payout of companies in which they own shares based on the nationality and share ownership portion of the Chief Executive.

This study is a platform on which subsequent research can be built, especially in Sub-Saharan Africa. However, there may be need for a wider scope of data from the region to facilitate a better understanding of the determinants of dividend policy.

\section{REFERENCES}

Aharony, J \& Swary, I. 1980, 'Quarterly Dividend and Earnings Announcements and Stockholders' Returns: An Empirical Analysis' The Journal of Finance, vol. 35, pp. 1-12.

Al Ghazali, A 2014, 'The Economic and Behavioural Factors Affecting Corporate Dividend Policy: Theory And Evidence. University Of Bath.

Allen, F Bernardo, AE \& Welch, I 2000, 'A Theory Of Dividends Based On Tax Clienteles' The Journal of Finance, vol. 55, pp. 2499-2536.

Alzahrani, M \& Lasfer, M 2012, ' Investor Protection, Taxation, And Dividends' Journal of Corporate Finance, vol. 18, pp. 745-762.

Apesteguia, J Azmat, G \& Iriberri, N 2012, 'The Impact of Gender Composition on Team Performance and Decision Making: Evidence from the Field' Management Science, vol. 58, pp. 78-93.

Bacon, F \& Kania, SL 2005, 'What Factors Motivate The Corporate Dividend Decision?'

Baker, M \& Wurgler, J 2004, 'Appearing And Disappearing Dividends: The Link To Catering Incentives' Journal Of Financial Economics, vol. 73, pp. 271-288.

Berger, PG Ofek, E \& Yermack, DL 1997, 'Managerial Entrenchment And Capital Structure Decisions' The Journal of Finance, vol. 52, pp. 1411-1438.

Brounen, D De Jong, A \& Koedijk, K 2006, 'Capital Structure Policies In Europe: Survey Evidence' Journal of Banking \& Finance, vol. 30, pp. 1409-1442.

Caliskan, D \& Doukas, JA 2015, 'CEO Risk Preferences and Dividend Policy Decisions' Journal of Corporate Finance, vol. 35, pp. 18-42.

Carter, DA Simkins, BJ \& Simpson, WG 2003, 'Corporate Governance, Board Diversity and Firm Value' Financial Review, vol. 38, pp. 33-53.

Chen, J Leung, WS \& Goergen, M 2017, 'The Impact of Board Gender Composition on Dividend Payouts; Journal of Corporate Finance, vol. 43, vol. 86-105.

Coles, JL Daniel, ND \& Naveen, L 2006, 'Managerial Incentives And Risk-Taking' Journal of 
European Journal of Accounting, Auditing and Finance Research

Vol.8, No. 6, pp.46-63, June 2020

Published by ECRTD-UK

Print ISSN: 2053-4086(Print), Online ISSN: 2053-4094(Online)

Financial Economics, vol. 79, pp. 431-468.

Crossland, C \& Hambrick, DC 2007, 'How National Systems Differ in their Constraints on Corporate Executives: A Study of CEO Effects in Three Countries' Strategic Management Journal vol. 28, iss. 8, pp 767-789.

Croson, R \& Gneezy, U 2009, 'Gender Differences In Preferences' Journal of Economic Literature, vol. 47, pp. 448-74.

Dalmácio, FZ \& Corrar, LJ 2007. 'A Concentração Do Controle Acionário E A Política De Dividendos Das Empresas Listadas Na Bovespa: Uma Abordagem Exploratória À Luz Da Teoria De Agência' Revista De Contabilidade E Organizações, vol. 1, pp. 17.

Davis, PS Babakus, E Englis, PD \& Pett, T 2010, 'The Influence of CEO Gender on Market Orientation and Performance in Service Small and Medium Sized Service Businesses' Journal of Small Business Management, vol. 48, pp. 475-496.

Deangelo, H Deangelo, L \& Stulz, RM 2006, 'Dividend Policy and the Earned/Contributed Capital Mix: A Test of the Life-Cycle Theory' Journal of Financial Economics, vol. 81, pp. 227254.

Deshmukh, S Goel, AM \& Howe, KM 2013, CEO Overconfidence and Dividend Policy' Journal of Financial Intermediation, vol. 22, pp. 440-463.

Easterbrook, FH 1984, 'Two Agency-Cost Explanations of Dividends' The American Economic Review, vol. 74, pp. 650-659.

Elton, EJ \& Gruber, MJ 1970, 'Homogeneous Groups and the Testing of Economic Hypotheses' Journal Of Financial and Quantitative Analysis, vol. 4, pp. 581-602.

Elyasiani, E \& Zhang, L 2015, CEO Entrenchment and Corporate Liquidity Management' Journal of Banking \& Finance, vol. 54, pp. 115-128.

Farinha, J 2003, 'Corporate Governance: A Survey of the Literature' SSRN Electronic Journal

Farrar, DE Farrar, DF \& Selwyn, LL 1967, 'Taxes, Corporate Financial Policy and Return to Investors' National Tax Journal, vol. 20, pp. 444-454.

Feng, Z Ghosh, C He, F \& Sirmans, C 2010, 'Institutional Monitoring and REIT CEO Compensation. The Journal of Real Estate Finance and Economics, vol. 40, pp. 446-479.

Fluck, Z 1999, 'The Dynamics of the Management-Shareholder Conflict' The Review of Financial Studies, vol. 12, pp. 379-404.

Forti, CAB Peixoto, FM \& Alves, DL 2015, 'Determinant Factors of Dividend Payments in Brazil' Revista Contabilidade \& Finanças, vol. 26, pp. 167-180.

Francis, BB Hasan, I John, K \& Song, L 2011, 'Corporate Governance and Dividend Payout Policy: A Test Using Antitakeover Legislation' Financial Management, vol. 40, pp. 83112.

Francoeur, C Labelle, R \& Sinclair-Desgagné, B 2008, 'Gender Diversity in Corporate Governance and Top Management' Journal of Business Ethics, vol. 81, pp. 83-95.

Ghosh, C \& Sirmans, C 2006. 'Do Managerial Motives Impact Dividend Decisions in REITS? The Journal of Real Estate Finance and Economics, vol. 32, pp. 327-355.

Gompers, P Ishii, J \& Metrick, A 2003, 'Corporate Governance and Equity Prices' The Quarterly Journal of Economics, vol. 118, pp. 107-156.

Guney, Y \& Ozkan, A 2005, 'New Insights on the Importance of Agency Costs For Corporate Debt Maturity Decisions' Applied Financial Economics Letters, vol. 1, pp. 233-238.

Hambrick, DC 2007, 'Upper Echelons Theory: An Update' Academy of Management Review vol. 
European Journal of Accounting, Auditing and Finance Research

Vol.8, No. 6, pp.46-63, June 2020

Published by ECRTD-UK

Print ISSN: 2053-4086(Print), Online ISSN: 2053-4094(Online)

32, no. 2 pp. 334-343.

Hu, A \& Kumar, P 2004, 'Managerial Entrenchment and Payout Policy' Journal of Financial And Quantitative Analysis, vol. 39, pp. 759-790.

Jalbert, T Chan, C Jalbert, M \& Landry, SP 2007, "The Interrelationship of CEO Nationality with Financial Management, Firm Performance, and CEO Compensation'.

Jensen, MC 1986, 'Agency Costs of Free Cash Flow, Corporate Finance, and Takeovers' The American Economic Review, vol. 76, pp. 323-329.

Jo, H \& Pan, C 2009, 'Why Are Firms With Entrenched Managers More Likely To Pay Dividends?' Review of Accounting And Finance, vol. 8, pp. 87-116.

Joecks, J Pull, K \& Vetter, K 2013, 'Gender Diversity in the Boardroom and Firm Performance: What Exactly Constitutes A “Critical Mass?” Journal of Business Ethics, vol. 118, pp. 6172.

Kanter, RM 1977, Work And Family In The United States: A Critical Review And Agenda For Research And Policy, Russell Sage Foundation.

Khan, T 2006, 'Company Dividends and Ownership Structure: Evidence From UK Panel Data' The Economic Journal, 116.

La Porta, R Lopez DeSilanes, F Shleifer, A \& Vishny, RW 2000, 'Agency Problems and Dividend Policies Around The World' The Journal Of Finance, vol.55, pp. 1-33.

Lease, RC John, K Kalay, A Loewenstein, U \& Sarig, OH 2000, 'Dividend Policy: Its Impact On Firm Value' Harvard Business School Press, Boston, Massachusetts.

Likitratcharoen, D 2011, 'CEO Reputations And Dividend Payouts' International Conference On Economics, Business And Management Ipedr, 2011.

Likitratcharoen, D Jiraporn, P \& Kanitpong, T 2012, 'Propensity To Pay Dividends And CEO Reputation' European Journal of Scientific Research, vol. 82, pp. 82-88.

Martin, AD Nishikawa, T \& Williams, MA 2009, 'CEO Gender: Effects On Valuation And Risk' Quarterly Journal of Finance And Accounting, 23-40.

Miller, MH \& Modigliani, F 1961, 'Dividend Policy, Growth, And The Valuation Of Shares' The Journal of Business, vol. 34, pp. 411-433.

Morck, R Shleifer, A \& Vishny, RW 1988, 'Management Ownership And Market Valuation: An Empirical Analysis' Journal of Financial Economics, vol. 20, pp. 293-315.

Naceur, S Goaied, M \& Belane, SA 2006, 'On The Determinants And Dynamics Of Dividends Policy'. International Review of Finance, vol. 6.

Nnadi, M Wogboroma, N \& Kabel, B 2013, 'Determinants of Dividend Policy: Evidence From Listed Firms In The African Stock Exchanges' Panoeconomicus, vol. 60, pp. 725-741.

Onali, E Galiakhmetova, R Molyneux, P \& Torluccio, G 2016, 'CEO Power, Government Monitoring, And Bank Dividends' Journal of Financial Intermediation, vol. 27, pp. 89117.

Ozkan, A \& Ozkan, N 2004, 'Corporate Cash Holdings: An Empirical Investigation Of UK Companies' Journal of Banking \& Finance, vol. 28, pp. 2103-2134.

Patra, T Poshakwale, S \& Ow-Yong, K 2012, 'Determinants of Corporate Dividend Policy In Greece' Applied Financial Economics, vol. 22, pp. 1079-1087.

Pawlina, G \& Renneboog, L 2005, 'Is Investment Cash Flow Sensitivity Caused By Agency Costs Or Asymmetric Information? Evidence From The UK' European Financial Management, vol. 11, pp. 483-513. 
European Journal of Accounting, Auditing and Finance Research

Vol.8, No. 6, pp.46-63, June 2020

Published by ECRTD-UK

Print ISSN: 2053-4086(Print), Online ISSN: 2053-4094(Online)

Pinheiro Holanda, A \& Dias Coelho, AC 2012. 'Dividendos E Efeito Clientela: Evidências No Mercado Brasileiro. Rae-Revista De Administração De Empresas, 52.

Rozeff, MS 1982, 'Growth, Beta And Agency Costs As Determinants of Dividend Payout Ratios' Journal of Financial Research, vol. 5, pp. 249-259.

Setia Atmaja, L Tanewski, GA \& Skully, M 2009, 'The Role of Dividends, Debt And Board Structure In The Governance Of Family Controlled Firms' Journal $f$ Business Finance \& Accounting, vol. 36, pp. 863-898.

Shakir, R 2009, 'International Articles: Examining The Effect Of Leadership Structure And Ceo Tenure On Malaysian Property Firm Performance Journal of Real Estate Literature, vol. 17, pp. 45-62.

Shrader, CB Blackburn, VB \& Iles, P 1997, 'Women In Management And Firm Financial Performance: An Exploratory Study' Journal of Managerial Issues, 355-372.

Stulz, R 1988, 'Managerial Control Of Voting Rights: Financing Policies And The Market For Corporate Control' Journal of Financial Economics, vol. 20, pp. 25-54.

Turner, JD, Ye, Q \& Zhan, W 2013, 'Why Do Firms Pay Dividends?: Evidence From An Early And Unregulated Capital Market' Review of Finance, vol. 17, pp. 1787-1826.

Van Pelt, T 2013, 'The Effect of Board Characteristics on Dividend Policy' Unpublished Working Paper, Tilburg School of Economics And Management, Department of Finance. Tilburg University: The Netherlands, 1-62.

Zwiebel, J 1996, 'Dynamic Capital Structure Under Managerial Entrenchment' The American Economic Review, 1197-1215.

\section{APPENDICES}

\section{Appendix I}

Table 10: Kruskal-Wallis Result for CEO Share Ownership and Dividend payout

\begin{tabular}{|r|l|r|}
\hline $\begin{array}{l}\text { CEO Share } \\
\text { Ownership }\end{array}$ & Observations & Rank Sum \\
\hline 0 & 178 & 31917.50 \\
\hline .01 & 5 & 381.50 \\
\hline .02 & 17 & 3286.00 \\
\hline .03 & 13 & 1553.00 \\
\hline .04 & 6 & 762.50 \\
\hline .05 & 8 & 1152.00 \\
\hline .06 & 1 & 102.00 \\
\hline .07 & 1 & 184.00 \\
\hline .08 & 6 & 1615.00 \\
\hline .09 & 2 & 311.50 \\
\hline .1 & 4 & 731.00 \\
\hline .11 & 2 & 255.00 \\
\hline .12 & 3 & 651.50 \\
\hline .13 & 3 & 537.50 \\
\hline .14 & 2 & 262.50 \\
\hline .15 & 9 & 1364.50 \\
\hline .23 & 1 & 205.00 \\
\hline .26 & 3 & 726.50 \\
\hline .27 & 1 & 209.50 \\
\hline
\end{tabular}


European Journal of Accounting, Auditing and Finance Research

Vol.8, No. 6, pp.46-63, June 2020 Published by ECRTD-UK

Print ISSN: 2053-4086(Print), Online ISSN: 2053-4094(Online)

\begin{tabular}{|c|c|c|}
\hline .31 & 1 & 179.50 \\
\hline .32 & 1 & 120.50 \\
\hline .37 & 1 & 22.50 \\
\hline .39 & 2 & 132.00 \\
\hline .4 & 2 & 130.50 \\
\hline .41 & 1 & 92.00 \\
\hline .65 & 1 & 8.00 \\
\hline .69 & 1 & 188.00 \\
\hline .73 & 2 & 107.50 \\
\hline .74 & 1 & 47.00 \\
\hline .75 & 1 & 42.00 \\
\hline .82 & 1 & 38.50 \\
\hline 1.58 & 1 & 66.50 \\
\hline 1.66 & 1 & 227.50 \\
\hline 1.7 & 1 & 229.00 \\
\hline 1.79 & 1 & 95.00 \\
\hline 1.89 & 1 & 238.00 \\
\hline 1.9 & 1 & 233.00 \\
\hline 1.96 & 1 & 235.00 \\
\hline 1.99 & 1 & 72.00 \\
\hline 2.05 & 2 & 172.50 \\
\hline 2.75 & 4 & 32.00 \\
\hline 2.87 & 1 & 70.00 \\
\hline 3.18 & 1 & 101.00 \\
\hline 3.39 & 1 & 135.00 \\
\hline 3.45 & 4 & 540.00 \\
\hline 6.05 & 1 & 63.00 \\
\hline 8.93 & 1 & 57.50 \\
\hline 9.29 & 1 & 49.00 \\
\hline 10.56 & 1 & 22.50 \\
\hline 12.13 & 3 & 194.50 \\
\hline 12.15 & 1 & 8.00 \\
\hline 12.18 & 1 & 18.00 \\
\hline 13.68 & 4 & 504.00 \\
\hline 18.11 & 4 & 303.50 \\
\hline 18.19 & 1 & 168.00 \\
\hline 32.35 & 1 & 209.50 \\
\hline
\end{tabular}

Chi-square $=86.307$ with 55 degrees of freedom Probability $=\mathbf{0 . 0 0 4 5}$

Chi-square with ties $=86.317$ with 55 degrees of freedom Probability $=\mathbf{0 . 0 0 4 4}$ 